\title{
Towards an evolutionary political economy. Editorial to the inaugural issue of the Review of Evolutionary Political Economy REPE
}

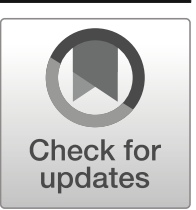

\section{Silvano Cincotti ${ }^{2}$ - Wolfram Elsner ${ }^{1}$ - Nathalie Lazaric ${ }^{3}$. Anastasia Nesvetailova ${ }^{4} \cdot$ Engelbert Stockhammer $^{5}$}

Published online: 30 June 2020

(C) The Author(s) 2020

\section{Introduction}

This is the first of two inaugural issues of the Review of Evolutionary Political Economy (REPE), a new peer-reviewed, inter-disciplinary academic journal, initiated by the European Association for Evolutionary Political Economy (EAEPE) and published by one of the leading international academic publishers, Springer Nature.

But why a new journal? Is there a potential space for it in the universe of already well-established economic journals? And what could its value-added for the economics community be?

The ambition of the journal is to bring together and integrate political economy, evolutionary and institutional economics, agent-based computational economics, and heterodox macroeconomics, and to become a pluralistic forum of excellence in what is emerging as evolutionary political economy.

Economics got separated from the social sciences in the late nineteenth century, when its later mainstream turned from "political economy" to "pure economics", which in turn, led to "neoclassical economics". A substantial further narrowing of that mainstream took place from the 1970 s onwards. With the "New Classical" counterrevolution, the Keynesian-neoclassical truce of the post-war period was ended. This transformed, in particular, the field of macroeconomics. A new mainstream economics was established, based on methodological individualism, particularly "rational

Wolfram Elsner

welsner@uni-bremen.de

1 University of Bremen, Bremen, Germany

2 University of Genoa, Genoa, Italy

3 Université Côte d'Azur, CNRS, Nice, France

4 City University London, London, UK

5 King's College London, London, UK 
expectations", and the notion of market clearing. "Proper" economics then had to use a particular mathematical modelling, and the models themselves had to be based on "rational" agents. In "New Classical" macroeconomics, a rational-expectations and global-knowledge equilibrium became the reference point of modelling in the form of the dynamic stochastic general equilibrium (DSGE) models.

In economics, such reductionism marginalized the different strands of nonmainstream economics. It became more difficult for non-orthodox and epistemologically pluralistic economists to publish in orthodox journals, to win grant funding and get promotion.

But it also led to some fragmentation among the non-mainstream scene, where heterodox economists of Marxist, post-Keynesian, institutionalist, socio-economic, feminist, ecological, or neo-Schumpeterian economics developed their own fields, established journals and associations. And several generalist, heterodox and pluralist organizations and networks, EAEPE being prominent among them, emerged in order to facilitate discussion, interaction and potential convergence among the disparate heterodox streams.

$R E P E$ now has been founded on the conviction that the fragmentation of the heterodox economic perspectives and the separation of "economics" and "political economy" is a severe impediment to progress in economic research and relevant insight for our societies. Below, we will briefly give an outline of some research orientations in the different fields to be covered by REPE, before we will discuss what we see as the particular role and value-added of this journal.

\subsection{Building blocks: evolutionary economics, original institutional economics, complexity economics, post-Keynesian economics, and international political economy}

The ambition of Evolutionary Economics in general is to interpret change and to observe the development (or history) of socio-economic systems, either by a formal dynamic system or by its qualitative reconstruction (or by both). Evolutionary approaches, paradigms, or theories integrate bounded rationality in dealing with complex problems, radical uncertainty, search, knowledge acquisition, and learning (Dosi and Winter 2003: 286). They receive inspiration from biology and biological analogies, but also from other natural sciences with their complex dynamic approaches and network modelling, such as physics or neuroscience. Those insights have entailed a renewal in the economics discipline and a new broad interdisciplinary cooperation.

Most heterodoxies in economics, among them are neo-Schumpeterian, Veblenian, radical, post-Keynesian, or Hayekian, interpret evolutionary dynamics in the context of socially learned and interactively acquired social rules and institutions, as coordination, cooperation, orientation, and complexity-reducing devices, and as interim social "solutions", or transient "attractors" in complex dynamics, but also possibly as dysfunctional, "petrified" structures preventing favourable change, impeding innovation, or causing petrifactions of systems (e.g. Dopfer and Potts 2004; Witt 2008; Elsner 2017a; Dosi et al. 2019). Such approaches rest upon a relatively recent transdisciplinary scientific corpus, characterized by a diversity of methods in addressing change, innovation, process, slower or faster transitions, and institutional and organizational solutions with shorter or longer, useful, or hindering states of systems. In these approaches, 
there can be no unique and globally optimal way of doing things, but agents and organizations have to adhere to social institutions, habits, routines, or norms, which lead to systemic path dependence (e.g. Becker et al. 2005).

Evolutionary approaches have not been completely standardized yet as to their methods, giving rise to a profusion of answers to address the questions of dynamics, process, history, novelty, or disruption. But among key findings of evolutionary economics are explanations showing why the "optimal" technology may not be realized (e.g. David 1985), why learning, adaptation, and building absorptive capacities are critical for technology diffusion, and how, once a technology is adopted, path dependency occurs, reinforcing prior choices (e.g. Cowan 1990). This was formally depicted first in W.B. Arthur's famous model of competing technologies (Arthur 1989).

Related applied evolutionary insights gained considerable impact on contemporary research and innovation policies, namely, in the EU. Industrial and organizational economics, the evolution of demand and consumption, questions of the natural environment, or the natural commons, including the global climate, and the transformations of the capitalist system, all were substantially broadened by evolutionary approaches.

While neo-Schumpeterian evolutionary theory relies upon a positive vision of innovation, a vector of growth and progress taken as a whole (e.g. Dosi and Grazzi 2006; Dosi et al. 2019), Veblenian evolutionary-institutional perspectives also focus on "ceremonial" degenerations, obstruction, distortion, or negative externalities of technologically innovative potentials (e.g. Elsner 2020).

The evolution of demand and consumption, analyzed already by Veblen, was further developed more recently, for instance based on work by U. Witt and others (e.g. Witt 2003, 2008; Lazaric et al. 2019). An evolutionary economics of consumption and demand scrutinizes preferences and values, which is symptomatic of evolutionary research responding to contemporary problems (e.g. Buensdorf and Cordes 2008; Cordes and Schwesinger 2014). This includes research within interdisciplinary socalled naturalistic perspectives, for instance on learning and transmission processes of new behaviour, such as in consumption qualified as "green". Work along these lines also makes evident the pertinence of environmental questions, which may become the new battle horse of evolutionary-institutional approaches as much as innovation and consumption, all in both research and policy (e.g. Maréchal and Lazaric 2010; Brouillat and Oltra 2012).

With respect to innovation, the long-standing lack of a critical stance towards innovation, failures to link innovation to social inclusiveness and ecological sustainability, and the reluctance to think about innovation in terms of governance and ownership have motivated the ambitions of the present journal. And there is much out already, where we can build upon (e.g. Metcalfe et al. 2005; Gifford and McKelvey 2019; Savona and Tommaso 2019).

While the evolutionary approach in a neo-Schumpeterian perspective focuses on innovation under the dialectic of destruction and creation and its different performances under more competitive versus oligopolistic and corporate conditions, the evolutionaryinstitutional approach in the Veblenian perspective (i.e. original institutional economics) focuses on the potentially different characters of social institutions as either problem-solving ("instrumental") or differential status and power preserving ("ceremonial") devices. And while neo-Schumpeterian economics has become leading in industrial economics, its ecologies, dynamics and evolution, and in research and innovation 
policies, the Veblenian neo-institutionalist "institutional dichotomy" has facilitated an operational and value-aware theory of "progressive" versus "regressive" institutional change to explain typical ongoing processes in contemporary capitalist socio-economies. Both evolutionary perspectives have considerably been further developed since the 1960s and 1970s into fruitful applied, applicable, empirically, and policy-wise accessible research programmes.

So, while neo-Schumpeterian economics has become the main paradigm shaping modern research and innovation policies, institutionalism, formerly looked at as "just historical" or "just sociological" by mainstream economists, had not only shaped US legal systems and social policies in the 1920s and 1930s but also, with a strong epistemological value-awareness, developed a policy paradigm of a "negotiated", socially problem-solving economy, based on its elaborated "instrumental value principles".

And both variants of evolutionary economics today also are deeply involved in "hetecon" discourses with political economy, post-Keynesianism, international political economy, or complexity economics, where potential convergences and complementarities are being fathomed (e.g. Elsner 2013, 2017b). Their policy conceptions do benefit from cooperation with political economy, the policy orientations of post-Keynesian economics and the field of International Political Economy, as well as their comprehensions of systems are benefiting from modern complexity sciences.

Besides the research in each of these fields, it is this structured interaction processes, discovering differences, complementarities, and convergences that will take place in REPE and guide its discourses and its pluralistic heterodox editorial policy.

The science of complexity studies phenomena, which emerge from a collection of interacting entities and which cannot be understood by considering them as separate units. In this sense, the holistic approach does not exclude a reductionist theory, but states that the aggregate can possess emerging properties that are different and complex with respect to the mere superposition of elementary objects. Complexity was proposed in the 1970s as counter paradigm to the reductionist methods in natural sciences (e.g. Anderson 1972), but already in 1959 and 1962, H.A. Simon prompted out the necessity of a holistic approach to the study of the economy, and in 1969, T.C. Schelling took up Simon's lesson with a study on segregation that led to first real applications of complexity sciences to social systems, with surprising, counterintuitive results. Since Simon's and Schelling's seminal works, the complexity approach has allowed to explain aggregate and emerging statistical regularities as well as both intuitive and counter-intuitive relationships in the economy, outcomes of the interaction of heterogeneous, and bounded-rational agents in either multiple equilibria or disequilibrium conditions of imperfect decentralized systems (markets) (e.g. Kirman 1992).

Complexity economics offered the opportunity to address questions that cannot be tackled by means of representative and perfectly rational agents in general-equilibrium conditions, whereas realistic explanations involve notions of heterogeneity, adaptive expectations, social collective intelligence and self-fulfilling or self-destroying properties, interactions, contagion, networks, etc.

Complexity economics is the answer to the needs of understanding all that, and it is nowadays the scientific area embracing all methodologies and applications of complexity sciences to economics, ranging from agent-based approaches (e.g. Arthur et al. 1997; Raberto et al. 2001; Delli Gatti et al. 2005; Le Baron 2006; Buchanan 2009; 
Cincotti et al. 2010; Farmer et al. 2012; Dosi and Roventini 2019) to networks (Battiston et al. 2007; Delli Gatti et al. 2010; Battiston et al. 2016), all in the general framework of non-linear dynamical complex systems (e.g. Arrow 1994; Arthur 1999; Beinhocker 2006; Helbing and Kirman 2013).

This also offers the opportunity to represent, analyze, and study economic and financial systems as complex adaptive systems and to translate them into artificial economies gathering insights and outcomes from different heterodox economic approaches (e.g. innovation, endogenous money, or financial acceleration) and taking fruitful inspiration and positive feedbacks from other disciplines (e.g. mathematics, physics, engineering, biology, or computer science) in a creative and valuable interand multidisciplinary context.

Post-Keynesian economics is an important heterodox macroeconomic theory that emphasizes demand-led growth, involuntary unemployment, and issues of financial instability (e.g. Lavoie 2009; Palley 1996; King 2002; Hein 2017). It builds on the radical insights of J.M. Keynes, in particular the concept of fundamental uncertainty, which implies that people cannot act in globally rational form and will resort to behavioural rules, which are often stabilized by social institutions and norms. This has important implications for the theory of money demand (liquidity preference), financial stability (the possibility of herding), and for investment dynamics, where nonrational elements, Keynes' "animal spirits", play an important role.

Post-Keynesian economics' initial project was to develop Keynes' macroeconomic theory, which had a short-term focus, into a growth theory (Robinson 1956; Kaldor 1956, 1957; Kalecki 1965) and to critique neoclassical theory of production and distribution (Cambridge capital controversies, e.g. Harcourt 1969; Moss 1980). It is based on a class-analytic approach and conventional, real-world behaviour rather than methodological individualism.

Also post-Keynesian economics formed into a distinct school of thought with its own journals and networks in the 1970s. Since then, it has developed theories of endogenous money creation (e.g. Moore, Lavoie), financial instability, and endogenous financial cycles (e.g. Minsky 1986; Palley 1994; Ryoo 2016; Nikolaidi and Stockhammer 2017 as a survey), demand regimes and growth models (e.g. Bhaduri and Marglin 1990; Lavoie and Stockhammer 2013), and stock-flow consistent modelling (Godley and Lavoie 2007). There is also a closely related stream of Latin American structuralism, which analyzes the growth conditions and constraints in developing countries (e.g. Cimoli and Porcile 2014).

Post-Keynesians have commented extensively economic policy making (e.g. Hein 2013; Stockhammer and Onaran 2013; Palley 2015), in particular questions of fiscal and monetary policy, critiqued austerity policies, and highlighted the danger of rising debt ratios for financial stability. Post-Keynesian economics has established itself as an alternative to mainstream macroeconomic theory addressing questions of demand formation, economic growth, distribution, and financial instability.

Compared with other heterodox approaches, post-Keynesian economics has paid less attention to modelling individual behaviour, but there are several areas of ongoing cooperation and intellectual cross fertilization with other heterodox approaches. As of yet, these are often limited to specific niches. For example, there is a recent wave of papers to integrate non-mainstream macroeconomics more systematically into ecological economics, and climate-change models in particular (e.g. Dafermos et al. 2017). 
There is also an exciting intersection of agent-based modelling and post-Keynesian economics (e.g. Caiani et al. 2016; Dosi et al. 2010); and there is a growing interest in the field of comparative political economy in the post-Keynesian analysis of demand regimes and growth models (e.g. Baccaro and Pontusson 2016; Schwartz and Tranoy 2019).

It is for such boundary-crossing research that $R E P E$ will be a forum.

Although it has long historical roots in moral philosophy and political economy, the contemporary discipline of International Political Economy (IPE) would re-emerge only in the late 1960s and 1970s at the intersection of international economics and international relations. At the time of the global ascent of market-centred ideologies and policies, some economists, as well as other social scientists, became dissatisfied with the lack of attention paid to of power relations in traditional economics. The analysis of power, in its multiple facets, had been central to political science and the study of international relations. The latter, in turn, traditionally focused on the analysis of monetary factors and trade regimes in shaping international economic diplomacy. While the founders of IPE included economists as well as political scientists, today the discipline is typically hosted in international relations and political science departments.

At present, IPE is divided by the so-called Atlantic divide (Cohen 2007). The American tradition of IPE has evolved by adopting the methods of neoclassical economics to the study of international trade diplomacy. As a result, American IPE today is dominated by quantitative methodologies and is defined by the focus on one main puzzle: Namely, if free markets are optimal allocators of scarce resources, how come that governments around the world continue to adhere to protectionism? Addressing this puzzle, American IPE employs, for instance, the method of two-level game theory, modelling the response of international economic agents against the context of (1) international and (2) domestic constituencies.

On the other side of the Atlantic divide, IPE has much stronger roots in classical political economy and history of economic thought, especially its Marxist tradition. This particular stream of scholarship remains prominent in the UK and continental Europe, where historically IPE has drawn on the French School of Regulation. The main themes for IPE in Europe have been globalization, neoliberalism, and the changing world order.

There is a third school of thought, somewhat less widely known, that informs IPE scholarship today. It goes back to the tradition of Original Institutional Economics (OIE), the above-mentioned evolutionary-institutional economics (or institutionalism), and the works of T.B. Veblen, J.R. Commons, A.A. Berle, and others. Its key focus has been twofold: On the one hand, it is the understanding of the structure and nature of wealth and capital; on the other, it is the relationship between individual and aggregate forms of organization and behaviour in capitalism. Although somewhat interrupted in its development by the ascent of quantitative approaches in mid-twentieth century, such evolutionary IPE has been given a boost by the 2007-2009 crisis. From around that time, it has been developing through a close dialogue between institutional economics, political economy, economic sociology, and law.

In this process, the focus on uncertainty and expectations, historically central to postKeynesian thought, has been advanced also by insights from OIE. Today, the essence of this approach is best captured by what Perry Mehrling called the "finance view" of the economy, which focuses on the present valuations of capital assets, seeing them as 
entirely dependent on imagined future cash flows, projected back into the present (Mehrling 2011: 4).

It is against this background that the discipline of IPE can particularly benefit from this new journal, $R E P E$, focusing on inter-disciplinary research in evolutionary political economy. It seems to become increasingly clear that today's economic institutions and structures are defined by expectations of change and valuations of the future. It also appears to be increasingly clear that big political-economic issues of today and tomorrow are likely to centre not on isolated or individual problems and crises, but on complex, systemic phenomena and processes. REPE is intended as an outlet that can inform the emergent evolutionary strand in IPE and related disciplines. The articles that comprise the inaugural issues should initiate discussions about the ways such discourses may develop.

Evolutionary economics, institutionalist economics, complexity theory, postKeynesian economics, and International Political Economy, all have important developed alternative perspectives to current mainstream economics. They all share a rejection of the rational-agent methodological individualism and of simple market clearing. Instead, they advocate an understanding of human behaviour as shaped by social institutions and conventions, of decentralized ("market") processes as prone to evolutionary dynamics that may lead to socially undesirable results and give rise to fallacies of composition.

Thus, we think that the various non-mainstream approaches in economics and the social sciences already share some common ontological, theoretical, and policyoriented ground, but they have developed in different fields and have built their own niches.

We think it is important to build more bridges between these and also other heterodox approaches (like feminist or ecological economics) to support the works towards comprehensive alternative visions of economics that could at some point absorb and replace the orthodox economic mainstream in research, applications, advice, policy-making, teaching, and textbook writing.

\subsection{Background and agenda of $R E P E$}

While initiated by EAEPE, REPE is organizationally independent as an academic journal and will be strictly international globally, both in its published articles and its personnel and governance (Editorial team, Associate Editors, and International Advisory Board).

EAEPE severely discussed the question of founding a new journal for several years. It considered that there are already a number of excellent heterodox and pluralist journals existing. There are well-established journals for evolutionary economics, institutional economics, political economy, post-Keynesian macroeconomics, complexity economics, and International Political Economy, furthermore, for innovation or history of economic thought, in Schumpeterian, Marxian, social-economic, institutionalist, Austrian, feminist, ecological, and other critical perspectives. There are also journals, both of a heterodox-pluralist and mainstream self-image, that cover cuttingedge methodologies, complex systems, networks, or computational approaches. But the editorial team of REPE, EAEPE, and Springer did identify a space indeed for a new pluralist-heterodox journal, which relates cutting-edge evolutionary and complex 
systems with institutional analysis, critical political economy, heterodox macroeconomics, computational methods, and interdisciplinarity, in a number of applied fields, from innovation, networks, distribution, or social class to climate change, with topicality and critical policy relevance, wherever possible.

For this, as our Aims\&Scope and Call for Papers clarify, we invite high-quality and cutting-edge conceptual and review articles, theoretical, methodological, empirical, and computational research from the fields and cross-fields mentioned. Submitted papers should embrace the heterogeneity of economic agents and interactions as complexified by power, institutions, or environmental conditions. Papers might explore the origins and impact of economic crises, inequality and unemployment, the changing role of finance and financial instability, the digital transformation, artificial intelligence, the socio-economic facets of environmental degradation, and climate change, up to most topical issues of economic impacts of epidemics. Articles that advance novel interdisciplinary analyses of complex systems, embrace social, natural, behavioural, and computer sciences or draw on humanities and cultural theories are highly welcome.

As a key purpose of $R E P E$ is to bring together different heterodox contributions, as sketched above, we will also rely on symposia (with 3-4 papers) and special issues (with 6-7 papers) on topical themes or themes that cut across conventional themes and disciplines and relate in some way to what may emerge as evolutionary political economy. Ideas and proposals from potential guest-editors are invited. Brief instructions are to be found on REPE's website:https://www.springer.com/journal/43253.

Each author will assign his/her paper to one of the major fields given by the Editorial Manager system when submitting. This should not be a restriction to the author but an assistance for quickly assigning the handling editor and reviewers.

Finally, to be successful, this journal needs support and critical feedback from critical scholars, including those beyond EAEPE. The editorial team always welcomes comments on REPE's agenda and issues.

\subsection{Outline of the present first inaugural issue (issue 1-2020)}

Against the background outlined, for the inaugural issues, we invited some of the leading figures in evolutionary political economy to reflect the status and future of what is, what could, and will be a research programme of evolutionary political economy. It turned out that we will be able to present to the scholarly public two inaugural issues, the present one and the next one, issue 2-2020, which will appear in Fall.

Smita Srinivas' article "Development, Institutional Variety, and the Future of Economics" explains the importance for development economics of diverse ontological assumptions about the nature and content of development for understanding and tackling institutional variety. The differences notably matter for understanding technological and social capabilities. Using four cases drawn from the author's research, this article highlights diverse conceptual frameworks for institutional variety. Such variety matters for economic development, and it is critical to understand local conditions and history of such variety. Indeed, industrialization is a process of institutional change, where social capabilities provide direction and guidelines for development goals and institutional transformation. By scrutinizing the process of inference during the building of capabilities, evolutionary political economy may improve the understanding of the emergence of that institutional variety and its outcomes within and across countries. 
In "The past, present and future of evolutionary macroeconomics", Malcolm Sawyer argues that heterodox macroeconomics contains many features of evolutionary political economy. It highlights social conflict and potential instabilities of monetary production economies in a world of fundamental uncertainty. Heterodox macroeconomics thus features reoccurring crises, distributional conflict, and gives rise to a path-dependent growth process. Sawyer particularly discusses three frontiers of heterodox macroeconomics that in the past have received limited attention: ecological issues and climate change, gender, and heterogeneous-agent modelling. Overall, he concludes that heterodox macroeconomics is part of evolutionary political economy that analyzes monetary production economies.

In "Gender and the Future of Macroeconomics: an evolutionary approach", Sheila Dow argues that gender lends itself well to an evolutionary analysis which focuses on non-equilibrium change and transformation for individuals within society. Decomposition by this important category, gender, helps us to understand the economy at the macro level, and design macroeconomic policy better. It also provides the foundation for advocating equal gender rights and outcomes. In contrast, in mainstream macroeconomics, gender issues can only be partially analysed due to its requirement of "microfoundations", its focus on GDP growth, and its explanation of suboptimal outcomes as due to market imperfections only. An approach which takes gender seriously requires the different epistemology that arises from feminism: It does not rely on dualistic categorisations, but builds on the idea of situated knowledge, which in turn requires a pluralist methodology and an acceptance of fundamental uncertainty. Such a methodology allows for emergent identity, for the cognitive roles of emotion and social convention, and for attention to power relations beyond market power.

John Davis' paper "Belief reversals as phase transitions and economic fragility: A complexity theory of financial cycles with reflexive agents" contributes to the analysis of expectations and belief reversals in an evolutionary and complexity economics framework. It formulates its analysis in terms of the concept of reflexivity, drawing on ideas on reflexivity in financial markets of G. Soros. It lays out a model of how a financial cycle expresses a systematic pattern of interacting feedback effects. The paper develops this analysis as a complex interaction between sets of heterogeneous expectations derived from the behaviour of reflexive economic agents. A central role is played by agents' beliefs and judgments underlying their expectations, and how those beliefs and judgments in uncertain circumstances are changeable and subject to abrupt reversals, which can manifest themselves in "Minsky moments". Agents' belief reversals may follow their misconceptions about causal processes in booms and upswings, and such misconceptions will reflect their tendency to think causally in terms of negative feedback patterns rather than positive ones.

In "Was Hyman Minsky a post-Keynesian economist?", Marc Lavoie discusses key features, and strengths and weaknesses, of Minsky's financial instability hypothesis, which became popular in the aftermath of the failure of Lehman Brothers despite having been ignored by mainstream economists until then. Minsky is an interesting case as he has been important within post-Keynesian theory, but was a student of Schumpeter's. His analysis of financial innovation and endogenous financial crisis has institutionalist and evolutionary features, while the core of his macroeconomics, including endogenous money creation via credit, and the principle of effective demand have clearly Keynesian features. While Colander, Holt and Rosser (2010), and 
Davidson (2003-4) have questioned whether Minsky can be classified, Lavoie concludes that indeed Minsky clearly stood in the post-Keynesian camp.

Frank Beckenbach's article, "A value-theoretic approach to economic dynamics and evolution - Synthesizing different Marxian modules in a simulation model. Part I: Foundations", has a twofold background as follows: first, the ongoing debate about whether the Marxian theory of value has been damaged (or even destroyed) by the alleged impossibility of solving the "transformation problem" and secondly, the fact that almost all of the (later) economic manuscripts of Marx are now accessible due to the MEGA project. In regard to the former, it can be concluded that the rationale of the Marxian value concept is distorted by its Ricardian elements (including the labour theory of value). In regard to the latter, the later economic manuscripts as well as the few economic monographs published during Marx's lifetime indicate that Marx was figuring out different modules for his value theory which are not thoroughly synthesized with each other. An attempt is made to reformulate this contested and fragmented value theoretic torso by focussing on the non-Ricardian essentials of the value theory. This (de-)construction is then used as a basis for linking the different value-theoretic modules in terms of their ability to explain economic evolution. In addition to a conceptual discussion of the value-theoretic modules, a simulation model is suggested for their integration. It can be shown that the value theory can be substantiated in a consistent stepwise fashion and the conditions for generating the long-term results expected by Marx can be specified.

As said, issue 2 will provide the second part of our two inaugural issues and will appear after the summer break with more papers on the future of the fields of evolutionary political economy by prominent authors (P. Arestis, F. Beckenbach, L. Chester, K. Dopfer, M. Lavoie, R. Palan, J. Toporowski, U. Witt). Enjoy reading REPE!

Funding Information Open Access funding provided by Projekt DEAL.

Open Access This article is licensed under a Creative Commons Attribution 4.0 International License, which permits use, sharing, adaptation, distribution and reproduction in any medium or format, as long as you give appropriate credit to the original author(s) and the source, provide a link to the Creative Commons licence, and indicate if changes were made. The images or other third party material in this article are included in the article's Creative Commons licence, unless indicated otherwise in a credit line to the material. If material is not included in the article's Creative Commons licence and your intended use is not permitted by statutory regulation or exceeds the permitted use, you will need to obtain permission directly from the copyright holder. To view a copy of this licence, visit http://creativecommons.org/licenses/by/4.0/

\section{References}

Anderson PW (1972) More Is Different. Science 177(4047):393-396

Arrow K (1994) Beyond General Equilibrium. In: Cowan G, Pines D, Meltzer D (eds) Complexity: metaphors, models, and reality. Addison-Wesley, Reading, pp 451-455

Arthur WB (1989) Competing technologies, increasing returns, and lock-in by historical events. Econ J 99(394):116-131

Arthur WB (1999) Complexity and the economy. Science 284:107-109 
Arthur WB, Holland JH, LeBaron BD, Palmer RG, Tayler P (1997) Asset pricing under endogenous expectations in an artificial stock market. In: Arthur WB, Durlauf S, Lane D (eds) The economy as an evolving complex system II. Addison-Wesley, Reading, pp 15-44

Baccaro L, Pontusson J (2016) Rethinking comparative political economy: the growth model perspective. Polit Soc 44(2):175-207

Battiston S, Delli Gatti D, Gallegati M, Greenwald B, Stiglitz JE (2007) Credit chains and bankruptcy propagation in production networks. J Econ Dyn Control 31(6):2061-2084

Battiston S, Farmer JD, Flache A, Garlaschelli D, Haldane AG, Heesterbeek H, Scheffer M (2016) Complexity theory and financial regulation. Science 351(6275):818-819

Becker M, Lazaric N, Nelson RR, Winter SG (2005) Applying organizational routines in understanding organizational change. Ind Corp Chang 14(5):775-791

Beinhocker E (2006) The origin of wealth: evolution, complexity, and the radical remaking of economics. Harvard Business School Press, Cambridge

Bhaduri A, Marglin S (1990) Unemployment and the real wage: the economic basis for contesting political ideologies. Camb J Econ 14:375-393

Brouillat E, Oltra V (2012) Dynamic efficiency of extended producer responsibility instruments in a simulation model of industrial dynamics. Ind Corp Chang 21(4):971-1009

Buchanan M (2009) Meltdown modelling. Could agent-based computer models prevent another financial crisis? Nature 460(6):680-682

Buensdorf G, Cordes C (2008) Can sustainable consumption be learned? A model of cultural evolution. Ecol Econ 67(4):646-657

Caiani A, Godin A, Caverzasi E, Gallegati M, Kinsella S, Stiglitz J (2016) Agent based-stock flow consistent macroeconomics: Towards a benchmark model. JEDCDH 69(C):375-408

Cimoli M, Porcile G (2014) Technology, structural change and BOP-constrained growth: a structuralist toolbox. Camb J Econ 38(1):215-223

Cincotti S, Raberto M, Teglio A (2010) Credit money and macroeconomic instability in the agent-based model and simulator Eurace. Economics 4(2010-26):1-32

Cohen B (2007) The transatlantic divide: why are American and British IPE so different. Rev Int Polit Econ 14(2):197-219

Colander D, Holt RPF, Rosser JB (2010) How to win friends and (possibly) influence mainstream economists. J Post Keynes Econ 32(3):397-408

Cordes C, Schwesinger G (2014) Technological diffusion and preference learning in the world of Homo sustinens: the challenges for politics. Ecol Econ 97(C):191-200

Cowan R (1990) Nuclear power reactors: a study in technological lock-in. J Econ Hist 50(3):541-567

Dafermos Y, Nikolaidi M, Galanis G (2017) A stock-flow-fund ecological macroeconomic model. Ecol Econ 131:191-207

David PA (1985) Clio and the economics of qwerty. Am Econ Rev 75(2):332-337

Davidson P (2003-4) Setting the record straight on a history of post keynesian economics. J Post Keynes Econ 26(2):245-272

Delli Gatti D, Di Guilmi C, Gaffeo E, Giulioni G, Gallegati M, Palestrini A (2005) A new approach to business fluctuations: heterogeneous interacting agents, scaling laws and financial fragility. J Econ Behav Organ 56(4):489-512

Delli Gatti D, Gallegati M, Greenwald B, Russo A, Stiglitz JE (2010) The financial accelerator in an evolving credit network. J Econ Dyn Control 34(9):1627-1650

Dopfer K, Potts J (2004) The evolutionary foundations of economics. In: Metcalfe JS, Foster J (eds) Evolution and Economic Complexity. Edward Elgar, Cheltenham, pp 3-23

Dosi G, Grazzi M (2006) Energy, Development, and the Environment: An Appraisal Three Decades After the "Limits to Growth" Debate, LEM Papers Series 2006/15, Laboratory of Economics and Management (LEM). Sant' Anna School of Advanced Studies, Pisa

Dosi G, Roventini A (2019) More is different... and complex! The case for agent-based macroeconomics. J Evol Econ 29(1):1-37

Dosi G, Winter SG (2003) Interprétation évolutionniste du changement économique: une étude comparative. Rev Econ 2:356-385

Dosi G, Fagioli G, Roventini A (2010) Schumpeter meeting Keynes, a policy-friendly model of endogenous growth and business cycles". Journal of Economic Dynamics and Control 34(9):1748-67

Dosi G, Pereira MC, Roventini A, Virgillito ME (2019) What if supply-side policies are not enough? The perverse interaction of flexibility and austerity. J Econ Behav Organ 162:360-388

Elsner W (2013) State and future of the "citadel" and of the heterodoxies in economics: challenges and dangers, Convergences and Cooperation. EJEEP 10(3):286-298 
Elsner W (2017a) Complexity economics as heterodoxy: theory and policy. J Econ Issues 51(4):939-978

Elsner W (2017b) Social economics and evolutionary institutionalism today. Theoretical components and "heterodox" convergence in a socio-economic perspective. Forum Soc Econ 46(1):52-77

Elsner W (2020) Innovation depends. Between sustainable change and destructive over-turbulence. On the complex "deep structure" of innovation. In: Dai S, Taube M (eds) China's Quest for Innovation. Institutions and Ecosystems. New York, Routledge, pp 10-49

Farmer JD, Gallegati M, Hommes CH, Kirman AP, Ormerod P, Cincotti S, Sanchez A, Helbing D (2012) A complex systems approach to constructing better models for managing financial markets and the economy. Eur Phys J-Spec Top 214(1):295-324

Gifford E, McKelvey M (2019) Knowledge-intensive entrepreneurship and S3: conceptualizing strategies for sustainability. Sustainability 11(18):4824

Godley W, Lavoie M (2007) Monetary economics. New York: Palgrave Macmillan

Harcourt G (1969) Some Cambridge controversies in the theory of capital. J Econ Lit 7(2):369-405

Hein E (2013) The crisis of finance-dominated capitalism in the euro area, deficiencies in the economic policy architecture, and deflationary stagnation policies. J Post Keynes Econ 36(2):325-354

Hein E (2017) Post-Keynesian macroeconomics since the mid-1990s - main developments. EJEEP 14(2): $131-172$

Helbing D, Kirman AP (2013) Rethinking economics using complexity theory. Real-World Econ Rev 64:2351

Kaldor N (1956) Alternative theories of distribution. Rev Econ Stud 23(2):83-100

Kaldor N (1957) A model of economic growth. Econ J 67:591-624

Kalecki M (1965) Theory of economic dynamics. Monthly Review Press, New York

King JE (2002) A history of post-Keynesian economics since 1936. Edward Elgar, Cheltenham

Kirman AP (1992) Whom or what does the representative individual represent? J Econ Perspect 6(2):117-136

Lavoie M (2009) Introduction to post-Keynesian economics. Palgrave Macmillan, New York

Lavoie M, Stockhammer E (2013) Wage-led growth: concept, theories and policies. In: Lavoie M, Stockhammer E (eds) Wage-led Growth. Palgrave Macmillan, London, pp 13-39

Lazaric, N., Le Guel, F., Belin, J., Oltra, V., Lavaud, S., Douai, A., 2019. Determinants of sustainable consumption in France: the importance of social influence and environmental values. Journal of Evolutionary Economics (forthcoming).

Le Baron B (2006) Agent-based Computational Finance. In Handbook of Computational Economics, vol 2. North Holland, Amsterdam

Maréchal K, Lazaric N (2010) Overcoming inertia: insights from evolutionary economics into improved energy and climate policy. Clim Pol 10(1):103-119

Mehrling P (2011) The New Lombard Street. Princeton University Press, Princeton

Metcalfe JS, James A, Mina A (2005) Emergent innovation systems and the delivery of clinical services: the case of intra-ocular lenses. Res Policy 34(9):1283-1304

Minsky HP (1986) Stabilizing an unstable economy. Yale University Press, New Haven

Moss S (1980) The end of orthodox capital theory. In: Growth, Profits and Property. In: Nell E (ed) Essays in the Revival of Political Economy. Cambridge University Press, Cambridge, pp 64-79

Nikolaidi M, Stockhammer E (2017) Minsky models. A structured review. J Econ Surv 31(5):1304-1331

Palley TI (1994) Debt, aggregate demand, and the business cycle: an analysis in the spirit of Kaldor and Minsky. J Post Keynes Econ 16(3):371-390

Palley TI (1996) Post Keynesian Economics. Debt, Distribution and the Macro Economy. Macmillan, London

Palley TI (2015) Escaping stagnation and restoring shared prosperity: a macroeconomic policy framework for job-rich growth. ILO Working Papers 994874713402676, Geneva: ILO

Raberto M, Cincotti S, Focardi SM, Marchesi M (2001) Agent-based simulation of a financial market. Physca A 299:319-327

Robinson J (1956) The accumulation of capital. Macmillan, London

Ryoo S (2016) Household debt and housing bubble: a Minskyan approach to boom-bust cycles. J Evol Econ 26:971-1006

Savona M, Tommaso C (2019) Structural changes and sustainability. A selected review of the empirical evidence. Ecol Econ 159:244-260

Schwartz H, Tranoy B (2019) "Thinking about thinking about comparative political economy: from macro to micro and back". Politics Soc 47(1):23-54

Stockhammer E, Onaran O (2013) Wage-led growth: theory, evidence, policy. Rev Keynes Econ 1(1):61-78

Witt U (2003) The evolving economy: essays on the evolutionary approach to economics. Edward Elgar, Cheltenham

Witt U (2008) What is specific about evolutionary economics? J Evol Econ 18(5):547-575 